\title{
O QUADRO LEGAL GERAL DA EXPLORAÇÃO E DA PRODUÇÃO DE PETRÓLEO NO MAR
}

THE GENERAL LEGAL FRAMEWORK FOR OFFSHORE OIL EXPLORATION AND PRO$D U C T I O N$ PETRÓLEO EN EL MAR

\section{Pierre-Jean Bordahandy ${ }^{1}$}

Resumo: Este artigo visa discorrer sobre as regras fundamentais que regulam as atividades de exploração e produção de petróleo no mar, que resultam da Convenção das Nações Unidas sobre o Direito do Mar (CNUDM III - 1982), e comparar as legislações domésticas de alguns dos países produtores de petróleo do oceano bem conhecidos, como Noruega, Reino Unido, Brasil e França, para analisar como têm abordado os desafios e as responsabilidades resultantes deste quadro. Este artigo pretende, ainda, analisar criticamente algumas decisões judiciais de interpretação e aplicação das legislações nacionais consideradas neste estudo.

1 Dr. Pierre-Jean Bordahandy - Senior Lecturer University of the South Pacific - Port Vila Vanuatu - pierrejean.bordahandy@usp.ac.fj - Bolsa CAPES / PNPD - UNISANTOS - 2015 - O autor gostaria de agradecer à Professora Eliane Octaviano Martins por seu apoio incondicional e ao Dr. Alexandre Machado pela assistência. 
Palavras-chave: Direito do Mar; Direito do Petróleo; produção de petróleo no mar; poluição dos oceanos, responsabilidade do Estado Costeiro.

Abstract: This article addresses the fundamental rules that regulate the activities of offshore oil exploration and production, which result from the United Nations Convention on the Law of the Sea (UNCLOS III - 1982), and to compare how the domestic legislations of some of the well-known offshore oil producing countries, such as Norway, the United Kingdom, Brazil, and France, have addressed the challenges and responsibilities arising from this framework. This article also gives a critical review of some judicial decisions of interpretation and application of the national legislations considered in this study.

Keywords: Law of the Sea, Petroleum Law, Offshore oil production, ocean pollution, coastal state responsibility.

Resumen: Este artículo tiene el propósito de discurrir sobre las reglas fundamentales que regulan las actividades de explotación y producción de petróleo en el mar, que resultan de la Convención de las Naciones Unidas sobre el Derecho del Mar (CNUDM III 1982), y comparar las legislaciones domésticas de algunos de los países muy conocidos por ser productores de petróleo del océano, como Noruega, Reino Unido, Brasil y Francia, para analizar cómo han abordado los desafíos y las responsabilidades resultantes de este cuadro. Este artículo pretende también analizar críticamente algunas decisiones judiciales de interpretación y aplicación de las legislaciones nacionales consideradas en este estudio.

Palabras clave: Derecho del Mar; Derecho del Petróleo; Producción de petróleo en el mar; Contaminación de los océanos; Responsabilidad del Estado Costero.

\section{INTRODUÇÃO}

ste breve estudo sobre o quadro legal da exploração e da produção petrolíferas no mar se interessa pelo Direito do Mar e, de forma subsequente, pela legislação nacional utilizada para regulamentar as atividades petrolíferas que acontecem além de suas costas. 
Das escolhas feitas pela regulamentação do Estado costeiro, e mais particularmente, da responsabilidade de proteção dos recursos e do meio ambiente decorrente do Direito do Mar em contrapartida da sua soberania sobre essas áreas, decorrem essencialmente dois problemas fundamentais em relação à exploração petrolífera no mar, tema que este estudo pretende abordar e destacar:

Primeiramente, existe um problema de execução dessa obrigação por parte de cada Estado costeiro, inclusive de coerência, colaboração e coordenação das políticas de proteção dos recursos e do meio ambiente entre os diferentes Estados costeiros.

Em segundo lugar, existe um problema de convivência entre a liberdade de navegação, consubstanciada pela lei da bandeira e o direito do Estado costeiro de exercer sua soberania em relação às atividades petrolíferas.

Estas questões são importantes se se considerar os recentes desastres ambientais marítimos causados pela produção de petróleo offshore com o acidente da Deepwater Horizon no Golfo do México nos EUA e com o acidente da plataforma (operada pela Chevron) no campo de Frade no Brasil. Esses acidentes relacionados às plataformas petrolíferas merecem nossa atenção, porque são a causa das maiores marés negras da história.

Além de esclarecer alguns conceitos de Direito do Mar, que são muitas vezes incompreendidos ou mal interpretados, este artigo visa também colocar em perspectiva as regras do Direito do Mar e as leis a elas relacionadas, de alguns Estados costeiros, a fim de colocar em evidência algumas inconsistências e lacunas existentes em nível de Direito Internacional, mas também do direito de alguns Estados.

Com isso em mente, este artigo adotará a metodologia de Direito Comparado para melhor destacar essas lacunas e inconsistências.

O impacto das atividades de plataformas de petróleo no mar manifesta-se em dois níveis: na superfície do mar, com a navegação e, no fundo dos oceanos. 
Essa dupla perspectiva leva a considerar nos desenvolvimentos a realidade das plataformas petrolíferas em relação às funções do mar e à definição de navio.

No contexto deste modesto artigo desenvolver-se-á somente a primeira parte desta dualidade de impacto das atividades petrolíferas. Abordar-se-á o desenvolvimento dos problemas associados com a ocupação das plataformas petrolíferas em relação à definição do navio em um próximo artigo.

\section{A OCUPAÇÃO DAS PLATAFORMAS PETROLÍFERAS EM RELAÇÃO ÀS FUNÇÕES DO MAR}

A implementação das plataformas de petróleo e sua interação com o solo e subsolo do domínio marítimo coloca questões tanto em nível do Direito do Mar, como do direito dos Estados costeiros. Por isso, é importante considerar ambos os aspectos da atividade das plataformas de petróleo.

\section{SEÇÃO I. A IMPLANTAÇÃO EM RELAÇÃO AO DIREITO INTERNACIONAL DO MAR}

Antes do surgimento do Direito do Mar, o princípio da liberdade dos mares tinha sido criado pelos britânicos que, dada a sua supremacia no domínio marítimo, tinham interesse em se deslocar livremente. ${ }^{2}$ Isso pressupõe que algumas considerações como sacrossanto foram baseadas em duas idéias:

A imensidão do mar gera uma impossibilidade de ocupação a longo prazo e, por conseqüência, o mar não é suscetível de propriedade pública ou privada. O mar não pode ser possuído.

Segundo o direito romano, tudo que é de uso inesgotável por sua natureza, não é feito para se tornar propriedade de ninguém, pois aquele que se torna proprietário não poderia ter mais uso do que ele tiraria estando no estado de indivisão. Assim, impedindo os outros de desfrutarem também, ele os prejudicariam por ter benefício para si mesmo, o que é contrário à lei da natureza. ${ }^{3}$

2 GROTIUS, Hugo. Mare Liberum, 1609

3 Em latim: "naturali jure Comunia sunt omniumhaec: aer, aqua, profluens et mare". 
São precisamente essas duas ideias que a exploração do petróleo no mar veio invalidar. Assim sendo, a criação do Direito do Mar era uma necessidade. O processo de desenvolvimento do Direito do Mar foi longo e tumultuado. Constituído por um conjunto de regras consuetudinárias, o Direito do Mar foi codificado pela primeira vez em 1958, pela Conferência de Genebra sobre o Direito do Mar, ${ }^{4}$ que resultou na assinatura de quatro convenções:

1. Convenção sobre o alto-mar.

2. Convenção sobre o Mar Territorial e a Zona Contígua.

3. Convenção sobre a plataforma continental.

4. Convenção sobre a pesca e a conservação dos recursos biológicos do alto-mar.

De maneira geral, o intuito das nações industrializadas era estabelecer a propriedade (dependendo da área) em seu espaço marítimo de proximidade; por sua vez, para os países em desenvolvimento, o objetivo era tentar minimizar os efeitos de uma insuficiência tecnológica para a exploração das riquezas que o mar contém. O Tratado de 1958, que deu aos Estados costeiros a propriedade do solo e subsolo marinho da plataforma continental, não alterou o regime das águas subjacentes, de modo que a função de comunicação, a priori, não mudou. No entanto, observa-se que as plataformas de petróleo instaladas na superfície do mar constituem, portanto, obstáculos à navegação.

Visto que a segunda conferência sobre o Direito do Mar não obteve sucesso, uma terceira conferência foi organizada. Após numerosas sessões, a Convenção de Montego Bay (Jamaica) sobre o Direito do Mar (UNCLOS III) 5 foi adotada.

4 ORGANIZAÇÃO DAS NAÇÕES UNIDAS. Convenção das Nações Unidas sobre a Plataforma Continental, $\mathrm{N}^{\circ}$ 7302. Treaty Series: Treaties and international agreements registered or filed and recorded with the Secretariat of the United Nations, New York, vol. 499, p. 311, 1965. Firmada em 26 de abril de 1958 em Geneva - vigente em 10 de junho de 1964. Disponível em: < https://treaties.un.org/doc/Publication/UNTS/Volume\%20499/v499.pdf >.Acesso em 25 de agosto de 2016.

5 ORGANIZAÇÃO DAS NAÇÕES UNIDAS. Convenção das Nações Unidas sobre o Direito do Mar - UNCLOS (com anexos, ato final e processo verbal de retificação do ato final em 3 de março de 1986 e 26 de julho de 1993), No 31363. Treaty Series, vol. 1834, I-31363, 1994. Firmada à Montego Bay em 10 de dezembro de 1982 - vigente em 16 de novembro de 1994. Disponível em: <www.un.org/depts/los/convention_agreements/texts/unclos/ unclos_f.pdf>. Acesso em 25 de agosto de 2016. 
Essa nova codificação internacional do Direito do Mar incluiu a maior parte das disposições da Convenção de 1958, especificando certos pontos (como a plataforma continental) e criando as Zonas Econômicas Exclusivas (ZEE). Mas, acima de tudo, foi certamente a Parte XI que gerou as maiores dificultades, pois atribuiu um estatuto legal para as águas profundas que se encontram depois da plataforma continental.

O direito do mar rege as atividades petrolíferas no mar em seis níveis:

1. A definição das diferentes áreas marinhas (demarcação, responsabilidade, direito e jurisdição sobre esses espaços...): mar territorial, zona contígua, ZEE, plataforma continental e alto-mar.

2. A criação de plataformas de petróleo no mar deve conciliar o princípio da liberdade de navegação por meio da criação de áreas seguras de tamanho razoável.

3. A obrigação de remover as plataformas ou estruturas abandonadas ou inutilizadas (incluindo plataformas) para garantir a segurança da navegação segundo as normas internacionais geralmente adotadas (diretrizes IMO).

4. O estabelecimento de regras para o leito e o subsolo localizados além dos limites da jurisdição de um Estado costeiro (várias partes contratantes manifestarão reservas sobre estas disposições).

5. As disposições gerais exigem que as partes contratantes devam tomar medidas para proteger e preservar o meio ambiente marinho e para lutar contra a poluição (especialmente contra a poluição por despejo por navios, resultante da atividade no fundo do mar ou de origem atmosférica).

6. O dever de cooperação das partes contratantes (em nível global ou regional) para lutar contra a poluição, para estabelecer regras e normas comuns e promover a pesquisa científica.

No entanto, essa influência do Direito do Mar sobre as atividades de exploração e produção se manifesta, sobretudo, num primeiro momento, por meio das divisões que ela efetua das diversas zonas marítimas e, em um segundo momento, 
por meio do estabelecimento de regras gerais que terão consequências sobre a atividade petrolífera.

A influência da divisão das zonas marítimas na produção e na exploração de petróleo

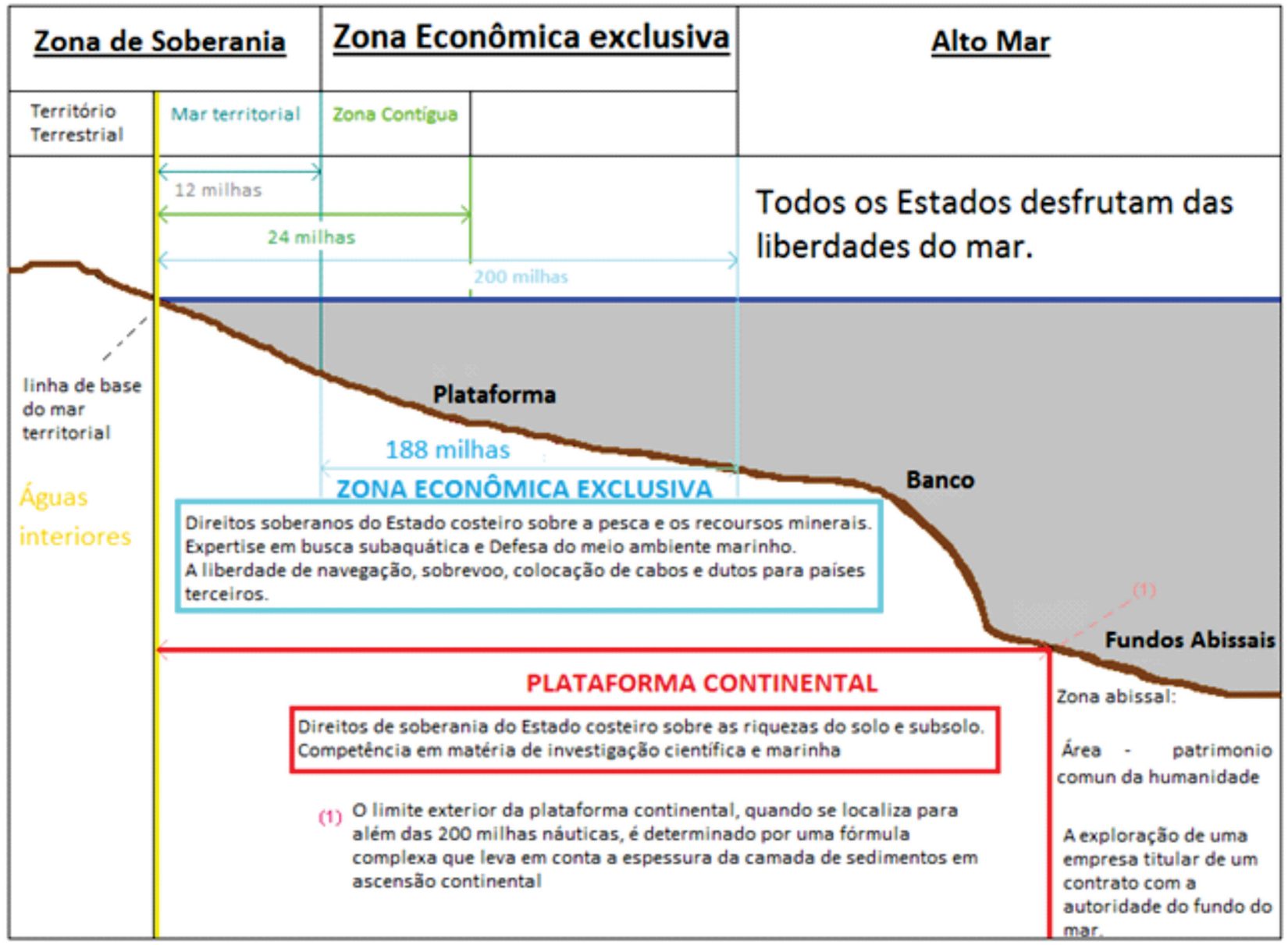

Figura 1 - UN.ORG

As plataformas petrolíferas são implantadas no fundo do mar para extração, mas ocupam também espaço na superfície. Essa dualidade de posição é a fonte de maior dificuldade, visto que seu regime jurídico deve obedecer a duas orientações contraditórias: apropriação de território e liberdade dos mares.

\section{As plataformas petrolíferas são implantadas no fundo do mar}

Considerando apenas o fundo do mar, as plataformas de petróleo podem se localizar em três áreas diferentes: no solo do mar territorial, na plataforma continental e nas águas profundas ou fundos marinhos. 


\section{As plataformas petrolíferas localizadas no solo do mar territorial}

No nível do mar territorial esse tipo de dualidade não suscita nenhum problema, pois o Estado costeiro dispõe de plena soberania, tanto sobre os fundos como sobre a superfície do mar. ${ }^{6}$

\section{As plataformas petrolíferas localizadas na plataforma continental}

A criação da plataforma continental é baseada na ideia de que alguns recursos marinhos não são renováveis, existindo, portanto, uma necessidade de apropriálos. A declaração do Presidente Truman, em 1945, tinha realmente a intenção de legitimar a apropriação pelo Estado dos recursos contidos no mar, mas essa foi apenas uma declaração política. $O$ argumento técnico usado na época para justificar tal apropriação era o da extensão marítima do território do Estado costeiro como uma continuidade física. ${ }^{7}$

A Convenção de Genebra sobre a Plataforma Continental, de 1958, teve, portanto, a intenção de justificar legalmente a apropriação desta parte do mar pelo Estado costeiro. A Convenção de 1982 reafirmou esse direito e adicionou outros.

\section{As definições dadas pelo Direito do Mar}

A definição da plataforma continental é dada pelo artigo $1^{\circ}$ da Convenção de $1958 .{ }^{8}$ Esta definição deve ser complementada com o artigo 3, que prevê que 6 O Artigo $21(1$, b) da Convenção de 1982 dá a responsabilidade ao Estado costeiro para regulamentar estas instalações «de acordo com as regras do direito internacional» (compreendida, como de acordo com o direito, a uma passagem inofensiva) : «O Estado costeiro pode adotar, em conformidade com os dispositivos da Convenção e com as outras regras do direito internacional, as leis e regras relativas à passagem inofensiva no mar territorial, que podem portar sobre as questões seguintes: a) segurança da navegação e regulação do tráfico marítimo, b) proteção dos equipamentos e sistemas de ajuda à navegação e de outros equipamentos ou instalações...».

7 Argumento fortemente criticado por alguns autores: «que a plataforma continental seja a extensão dos continentes é provável; mas não é certa. Você não pode basear uma teoria jurídica em uma teoria geológica não confirmada". Conforme: REMOND-GOUILLOU Martine.

L'exploitation petrolière en mer et le droit. Paris : Éditions Technip, 1970, p. 13.

8 ORGANIZAÇÃO DAS NAÇÕES UNIDAS. Convenção das Nações Unidas sobre a Plataforma 
os direitos dos Estados costeiros sobre a plataforma continental não afetam o regime jurídico das águas sobrejacentes.

Uma definição idêntica da plataforma continental é dada pelo artigo 76 da Convenção de 1982. O princípio da ausência de direito do Estado costeiro sobre as águas é reafirmado no artigo 78. A Convenção de 1982 destinava-se a corrigir a imprecisão do teste de usabilidade anexado aos limites exteriores da plataforma continental. Em todos os casos, quando o Estado costeiro deseja estabelecer os limites exteriores da plataforma além das 200 milhas, a CMB (Convenção de MontegoBay) prevê a intervenção da Comissão de Limites da Plataforma Continental (CLPC). ${ }^{9}$

Mesmo antes da criação dessa comissão (CLPC), três estados já haviam reivindicado uma extensão que se estende além das 200 milhas em $1993 .{ }^{10}$ Desde então, muitos Estados apresentaram pedidos de extensão da plataforma continental para a Comissão (CLPC), incluindo França e Brasil. Convém notar, porém, que o Brasil não parece ter aguardado pela aprovação da Comissão para tomar medidas no que diz respeito à plataforma continental que se estende para além das 200 milhas. ${ }^{11}$

Além da extensão de sua plataforma continental para além das 200 milhas náuticas, o Brasil também assinou um acordo para explorar as reservas da GuinéBissau em uma área considerada "reserva mundial" pela UNESCO. ${ }^{12}$ Um acordo semelhante sobre as reservas de petróleo da plataforma continental de Timor Leste foi assinado pela Austrália. ${ }^{13}$

Continental, $N^{\circ}$ 7302. Treaty Series: Treaties and international agreements registered or filed and recorded with the Secretariat of the United Nations, New York, vol. 499, p. 313.

9 ORGANIZAÇÃO DAS NAÇÕES UNIDAS. Convenção das Nações Unidas sobre o Direito do Mar - UNCLOS (com anexos, ato final e processo verbal de retificação do ato final em 3 de março de 1986 e 26 de julho de 1993), n 31363. Treaty Series, vol. 1834, I-31363, 1994. Artigo 76.

10 Jean-Pierre, CADENAT Philippe. Le droit de la mer dix ans après Montego-Bay. Droit maritime français, octobre 1993, n 531, p. 435.

11 BONIFASSI Marie-Laure. Montego Bay: 30 ans après. Appropriation et exploitation des espaces maritimes : état des lieux, droit, enjeux. Centre d'Études Supérieures de la Marine, p. 30. Disponível em: <http://cesm.marine.defense.gouv.fr/content/download/3762/54304/ file/CESM\%20Montego\%20Bay-bonne\%20version.pdf>. Acesso em: 25 de agosto de 2016.

12 BONIFASSI Marie-Laure. Montego Bay: 30 ans après, p.18.

13 TimorSea Treaty. Disponível em: <http://timor-leste.gov.tl/wp-content/uploads/2010/03/ R_2003_2-Timor-Treaty.pdf>. Acesso em: 25 de agosto de 2016. 
Outra definição importante a ser citada é a da Zona Econômica Exclusiva (ZEE), posto que uma plataforma de petróleo pode ser implantada simultaneamente na plataforma continental de um Estado costeiro e na sua ZEE. Segundo a Convenção de MontegoBay (CMB), a ZEE é definida pelos artigos 55 e 57 como uma área que se estende desde a linha de base do mar territorial até uma distância de 200 milhas. ${ }^{14}$

Outra ambição da Convenção de 1982 era propor um critério de delimitação das plataformas dos Estados tendo costas adjacentes ou opostas. A CMB finalmente escolheu o princípio de delimitação da plataforma continental feita por acordo, em conformidade com o Direito Internacional, tal como referido no artigo 38 do Estatuto da Corte International de Justiça para alcançar uma solução equitativa. ${ }^{15}$

Uma última definição relevante, que deve ser citada neste estudo, é a da ilha. Conforme definido na Convenção de 1982, artigo 121 (1) da CMB ${ }^{16}$ parece improvável que uma ilha seja capaz de absorver uma plataforma de petróleo, o que confirma explicitamente os artigos 5 (4) da Convenção de $1958^{17}$ e 60 (8) da CMB. ${ }^{18}$

\section{Natureza dos direitos dos Estados costeiros}

A legislação do mar confere três categorias de poderes aos Estados:

Prerrogativas para administrar as zonas marítimas

A justificativa legal para os direitos dos Estados sobre a plataforma continental se encontra no artigo 2 da Convenção de 1958 e no artigo 77 da CMB. ${ }^{19} \mathrm{O}$ 14 ORGANIZAÇÃO DAS NAÇÕES UNIDAS. Convenção das Nações Unidas sobre o Direito do Mar. Artigo 76 (Plataforma Continental).

15 ORGANIZAÇÃO DAS NAÇÕES UNIDAS. Convenção das Nações Unidas sobre o Direito do Mar (UNCLOS), Treaty Series, vol. 1834, Artigos 74 (Zona Econômica Exclusiva) e 83 (Plataforma Continental).

16 ORGANIZAÇÃO DAS NAÇÕES UNIDAS. Convenção das Nações Unidas sobre o Direito do Mar (UNCLOS), Treaty Series, vol. 1834. Artigo 121(1), p. 48, enuncia que: «Une île est une étendue naturelle de terre entourée d'eau qui reste découverte à marée haute».

17 ORGANIZAÇÃO DAS NAÇÕES UNIDAS. Convenção das Nações Unidas sobre a Plataforma Continental, Treaty Series, vol. 499, p. 315.

18 ORGANIZAÇÃO DAS NAÇÕES UNIDAS. Convenção das Nações Unidas sobre o Direito do Mar (UNCLOS), Treaty Series, vol. 1834. Artigo 60(8), p. 27, enuncia que: « Les îles artificielles, installations et ouvrages n'ont pas le statut d'îles. »

19 ORGANIZAÇÃO DAS NAÇÕES UNIDAS. Convenção das Nações Unidas sobre a Plataforma 
artigo 56 da CMB confere poderes semelhantes aos do Estado costeiro sobre sua ZEE. ${ }^{20}$

Uma análise preliminar dos artigos apresentados anteriormente revela que a plataforma continental é uma área marítima sujeita a uma competência para certas finalidades em oposição às zonas marítimas sujeitas à soberania absoluta do Estado costeiro. Isso significa que o exercício da competência do Estado costeiro sobre a plataforma continental é limitado a dois objetivos específicos: "para fins de exploração e para aproveitamento dos seus recursos naturais".

No que se diz respeito à plataforma continental, "os recursos naturais" são limitados aos recursos da própria plataforma, ou seja, recursos minerais e outros recursos não vivos do leito do mar e seu subsolo, e organismos pertencentes às espécies sedentárias. Isso é o que distingue a plataforma continental da ZEE, visto que esses direitos soberanos se estendem a todos os recursos naturais. Portanto, quando há uma ZEE, além da plataforma continental, a extensão espacial dos direitos do Estado costeiro até 200 milhas é duplamente garantida pelo artigo 77 e pelo artigo 56 da CMB.

Deve-se reter dessas disposições que, se o Estado costeiro tem obtido direitos exclusivos sobre esses recursos, é necessário gerenciá-los. Essa ideia aparece de maneira explícita no artigo 61 da $Z_{E E}^{21}$, mas também é subjacente à lógica geral da CMB e deve aplicar-se aos recursos do artigo 77 (plataforma continental).

\section{Prerrogativas sobre as estruturas}

O conteúdo do artigo 5 (4) da Convenção de 1958 é encontrado no artigo 60 (1) da CMB. Se o artigo 60 da CMB refere-se às instalações que estão a priori na ZEE, o seu conteúdo é aplicável mutatis mutandis à plataforma continental,

Continental, Treaty Series, vol. 499, p. 312. Artigo 2 enuncia que: « L'Etat côtier exerce sur son plateau continental les droits souverains aux fins d'exploration et d'exploitation de ses ressources naturelles ».

20 ORGANIZAÇÃO DAS NAÇÕES UNIDAS. Convenção das Nações Unidas sobre o Direito do Mar (UNCLOS), Treaty Series, vol. 1834. Artigo 56, p. 25.

21 ORGANIZAÇÃO DAS NAÇÕES UNIDAS. Convenção das Nações Unidas sobre o Direito do Mar (UNCLOS), Treaty Series, vol. 1834. Artigo 61: «Conservation des ressources biologiques », p. 27. 
conforme $\left(1^{\circ}\right)$ do artigo 80 . Note-se que a competência do Estado costeiro sobre essas estruturas é mencionada duas vezes na ZEE, como o artigo 56 (1) (b) (i) afirma jurisdição sobre a instalação e a utilização destas estruturas. Os poderes conferidos aos Estados costeiros são bastante amplos, de uma competência geral. 0 artigo 60 (2) mais especificamente refere-se à competência em impostos, direitos aduaneiros, saúde e, acima de tudo, segurança. No entanto essa distribuição de competência pode gerar dificultades em relação às estruturas que têm uma bandeira.

\section{Prerrogativas para um tipo determinado de atividades}

A CMB tem certas disposições específicas no que se diz respeito à exploração de petróleo do litoral do Estado em seu artigo $81^{22}$. Isso ilustra perfeitamente a ideia de gestão de recursos e da regulamentação das atividades, incluindo petrolíferas, pelo Estado costeiro. É interessante notar que o artigo 82 prevê uma espécie de retribuição à "autoridade" quando a extração de petróleo ocorre na plataforma continental além das 200 milhas. A presença da "autoridade", nesse caso, mostra o problema da implantação de plataformas petrolíferas em áreas onde o Estado costeiro tem menos prerrogativas.

Acaba-se de analisar brevemente os poderes do Estado costeiro sobre a plataforma continental e a ZEE. Antes de analisar o impacto de tais disposições sobre a superfície e, particularmente, sobre o princípio da liberdade dos mares, convém questionar: uma plataforma de petróleo poderia criar raízes para além da plataforma continental?

\section{As plataformas petrolíferas localizadas na área}

O artigo $136^{23}$ da CMB afirma que os recursos da "área" além das plataformas continentais, são "patrimônio comum da humanidade" e que os recursos dessa área podem ser apropriados segundo o regime previsto pela CMB.

22 ORGANIZAÇÃO DAS NAÇÕES UNIDAS. Convenção das Nações Unidas sobre o Direito do Mar (UNCLOS), Treaty Series, vol. 1834, p. 37. « L'Etat côtier a le droit exclusif d'autoriser et de réglementer les forages sur le plateau continental, quelles qu'en soient les fins. »

23 ORGANIZAÇÃO DAS NAÇÕES UNIDAS. Convenção das Nações Unidas sobre o Direito do Mar (UNCLOS), Treaty Series, vol. 1834. Artigo 136 p. 37 enuncia que: « La Zone et ses ressources sont le patrimoine commun de I'humanité. ». 
Para implementar esse princípio, a Convenção prevê a criação de duas instituições:

- De um lado, a "autoridade", um órgão de deliberação de decisão, que inclui todos os países signatários da Convenção.

- De outro lado, a "empresa", órgão responsável pelas operações na área.

A remuneração da "autoridade" pelo Estado Costeiro "patrocinador" da empresa que explora a "área", o modo de funcionamento da empresa e as normas aplicáveisà exploração dos minérios necessitam maiores esclarecimentos. É importante notar que, devido à oposição dos Estados desenvolvidos como Inglaterra, Estados Unidos e França, a Parte XI da UNCLOS III (CMB) foi modificada pelo "Acordo em Relação à implementação da Parte XI da UNCLOS CMB de 1982". ${ }^{24}$ Esse acordo permitiu a assinatura da CMB pela maioria dos países desenvolvidos, incluindo a adesão da União Européia (JO de 20 de agosto de 1994, nI.215). ${ }^{25}$

Vários países (França, China, Índia e outros) obtiveram o estatuto de investidor "pioneiro" da ONU. ${ }^{26}$ Pode-se, então, observar que, se num primeiro tempo, a parte XI do UNCLOS, com base na tese de patrimônio comum da humanidade do Doutor Pardo, provocou uma oposição por parte dos países industrializados, num segundo tempo, a segunda parece se impor. ${ }^{27}$

Também é interessante notar que a ocupação privada das águas na superfície das águas profundas sem interferência com o solo e o subsolo das águas profundas parece não desencadear o envolvimento da "Autoridade" e aparenta estar sujeita às regras de águas internacionais. Isso pode resultar da leitura conjugada dos artigos 133, 134 e 135 da CMB. Nesse nível, o projeto "Sea-Launch", que utiliza uma plataforma semissubmersível para o lançamento de foguetes em águas internacionais perto do Equador, não parece ter gerado receitas para o fundo do "patrimônio comum da humanidade". Esta constatação leva a se falar do impacto das plataformas de petróleo na superfície dos oceanos.

24 ONU - Agreement relating to the implementation of Part XI of the United Nations Convention on the Law of the Sea of 10 December 1982 Overview - ONU. Disponível em: <http://www. un.org/depts/los/convention_agreements/convention_overview_part_xi.htm>. Acesso em: 25 de agosto de 2016.

25 BONASSIES Pierre. Le droit positif Français en 1994. Droit Maritime Français, $\mathbf{n}^{\circ} \mathbf{3}, 1995$.

26 CHURCHILL Robin, LOWE Alan Vaughan. The Law of the Sea. 3 ed., Juris Publishing Inc, December 1999, p. 251. Law of The Sea Bulletin, n¹2, p. 39-40. Dezembro 1988.

27 BROWN Edward Duncan. The international Law of the Sea. The American Journal of International Law, v. I, p. 445-477, Jan. 1996. 


\section{A plataforma de petróleo ocupa um espaço na superfície do mar}

Depois de conceder direitos de soberania aos Estados costeiros sobre a ZEE e a plataforma continental, o Direito do Mar teve que tornar esses novos direitos compatíveis com os usos mais tradicionais do mar que ocorrem na superfície ou na água.

O ponto de partida de nossa análise é lembrar que, em qualquer caso, os direitos do Estado costeiro, tanto na plataforma continental como na sua ZEE, não afetam de modo algum o estado das águas que se encontram na sua superfície, o que foi especificado no artigo $58^{28}$ e no artigo 78 da $\mathrm{CMB}_{1}{ }^{29}$ como no artigo 3 da Convenção de $1958,{ }^{30} \mathrm{com}$ a afirmação do estatuto jurídico das águas que se encontram na superfície e a liberdade atribuída aos países terceiros, e o princípio da liberdade dos mares. Mas essa liberdade é condicional desde 1958 e é duplamente condicional desde 1982.

\section{Liberdade condicional em 1958}

Introduzidas em 1958, as zonas de segurança em torno de plataformas de petróleo são uma exceção ao princípio de liberdade dos mares, porque estão fechadas ao tráfego marítimo, bem como a qualquer outra atividade. ${ }^{31}$

28 ORGANIZAÇÃO DAS NAÇÕES UNIDAS. Convenção das Nações Unidas sobre o Direito do Mar - UNCLOS III, Treaty Series, vol. 1834. Artigo 58 e Artigo 80.

29 ORGANIZAÇÃO DAS NAÇÕES UNIDAS. Convenção das Nações Unidas sobre o Direito do Mar - UNCLOS III, Treaty Series, vol. 1834. Artigo 78: Regime Jurídico das águas e do aéreo sobrejacentes e direitos e liberdades de outros Estados.

"1. Os direitos do Estado costeiro sobre a plataforma continental não afetam o regime jurídico das águas sobrejacentes do espaço aéro acima dessas aguas.

2. O exercício dos direitos do Estado costeiro sobre a plataforma continental não deve afetar a navegação ou outros direitos e libertades dos demais Estados, previstos na presente Convenção, nem ter como resultado uma ingerência injustificada neles."

30 ORGANIZAÇÃO DAS NAÇÕES UNIDAS. Convenção das Nações Unidas sobre o Direito do Mar - UNCLOS II / Convenção de 1958. Artigo $3^{\circ}$ : Os direitos do Estado costeiro sobre a plataforma continental não afetam o regime das águas sobrejacentes como o alto-mar, nem o do espaço aéreo situado acima destas águas.

31 ORGANIZAÇÃO DAS NAÇÕES UNIDAS. Convenção das Nações Unidas sobre o Direito do Mar - UNCLOS, Treaty Series, vol. 1834, Artigo 80, p. 37, enuncia que «O Artigo 60 aplica-se, mutatis mutandis, às ilhas artificias, instalações e estruturas sobre a plataforma continen- 
O estabelecimento de zonas de segurança deve, na medida do possível, respeitar as rotas marítimas e estar de acordo com a resolução A.671(16) da OMI relativa às consequências da concessão (atribuída pelo Estado costeiro) de uma licença de ocupação da plataforma continental sobre o tráfego marítimo. Segundo a seção 7 da Resolução A572 (14) da OMI, uma zona de segurança que esteja de maneira permanente no caminho de uma rota marítima deve ser sujeita à declaração do Estado costeiro pela organização (IMO), a fim de adotar uma emenda para a rota em questão.

É necessário distinguir as zonas de segurança e as zonas cujo direito de ancorar e pescar é restringido, pois as zonas de segurança proíbem a simples passagem de navios e são geralmente estabelecidas para qualquer tipo de instalação ocupando um lugar na superfície.

De acordo com UNCLOS III, a zona de segurança não deve normalmente exceder 500 metros, mas o artigo 60 também se refere à consulta dos "padrões internacionais" para determinar otamanho dessas zonas em situações específicas ${ }^{32}$. Na Resolução A.671 (16) (Recomendação 1c), a IMO fornece as normas relativas à navegação nas proximidades de instalações offshore.

\section{Liberdade duplamente condicional desde 1982}

A ZEE confere ao Estado costeiro um direito que se estende a todos os recursos naturais (recursos das águas vivas ou subjacentes ao fundo do mar ou recursos minerais e no subsolo marinho). ${ }^{33}$ Esse regime específico da ZEE altera o estado das águas de superfície para as quais já não se fala mais de alto-mar, o que illustra a redução da liberdade do mar.

O projeto "Sea-Launch" também illustra essa redução de liberdade do mar, porque o posicionamento de uma plataforma para o lançamento de foguetes

tal». O Artigo 60 prevê que o Estado costeiro tem o dever quando for necessário de estabelecer as zonas de segurança nessas áreas e torná-las disponíveis a todos os interessados.

32 Sobre a resolução da OMI com relação às zonas de segurança, ver: BROWN Edward Duncan. The international Law of the Sea. Ed. Dartmouth, 1994, v. I, p. 273, nota n¹4.

33 ORGANIZAÇÃO DAS NAÇÕES UNIDAS, Convenção das Nações Unidas sobre o Direito do Mar - UNCLOS, Treaty Series, vol. 1834. Artigo 56, p. 25. 
em alto-mar é uma ocupação privada dessa zona. Se o artigo 87 da CMB parece permitir "a construção de ilhas artificiais", pode-se perguntar se a presença desse tipo de estrutura em alto-mar e se a criação de área de segurança nesse contexto são compatíveis com o estado dessa zona, especialmente quando os 500 metros de uma zona de segurança são claramente insuficientes para o lançamento de um foguete. Quid da applicação do sistema do "patrimônio comum da humanidade" ao alto-mar.

Acaba-se de apresentar brevemente os princípios gerais das zonas de competência (jurisdição) estabelecidos pelo Direito do Mar e as consequências da implantação geográfica das plataformas de petróleo. No entanto, o Direito do Mar também dispõe de outras regras aplicáveis às operações petrolíferas no mar.

\section{A influência de outras normas de Direito Internacional do Mar na exploração e na produção de petróleo}

Além dos deveres do Estado costeiro decorrentes das atividades autorizadas na sua plataforma continental e na sua ZEE, o Direito do Mar acrescenta obrigações específicas relativas à poluição, ao abandono das instalações offshore e à cooperação científica.

\section{As regras do Direito do Mar no que diz respeito à poluição}

A Parte XII da CMB / UNCLOS III, dedicada à proteção e à preservação do meio marinho, prevê uma série de direitos e obrigações adicionais para os Estados costeiros.

De maneira muito prática, os artigos 192 a 196 obrigam os Estados a proteger e preservar o meio marinho da exploração de recursos biológicos e minerais. Ademais, o artigo 198 do CMB exige que o Estado costeiro notifique outros Estados quando há dano iminente ou poluição atual, e o artigo 199 exige que colabore com outros Estados na luta contra a poluição. 
De maneira mais jurídica, o artigo 208 da CMB exige que os Estados costeiros adotem leis e regulamentos para prevenir, reduzir e controlar a poluição devido às atividades autorizadas por ele no leito do mar em áreas de sua competência. Mas, acima de tudo, além de regular e ajudar uns aos outros para lutar contra a poluição, os artigos 204 a 206 exigem que os Estados monitorem e realizem pesquisas sobre os riscos de poluição gerados pelas atividades permitidas em suas plataformas continentais.

Por fim, a obrigação de agir contra a poluição se manifesta de duas maneiras adicionais na CMB: em primeiro lugar, por meio do artigo 142, que autoriza a intervenção do Estado costeiro além do seu mar territorial para lutar contra a poluição e, em segundo lugar, por meio do artigo 197 que aprova um dever de cooperação dos Estados em nível regional para determinar normas aplicáveis contra a poluição em áreas determinadas devido à especificidade destas áreas ${ }^{34}$.

Regras relativas ao desmantelamento das instalações offshore no mar

A tolerância da ocupação do mar pelas plataformas petrolíferas é limitada no tempo e no espaço. O artigo 60 (3) do CMB obriga os Estados a limitarem as violações à liberdade de navegação dessas estruturas, efetuando seu desmantelamento quando não estiverem em uso. Entretanto, não há obrigação de desmantelar completamente as estruturas. O artigo 210 da CMB limita-se à carga e à competência do Estado costeiro para regular o abandono das instalações offshore tal como definidas no artigo 1 (b) da CMB. O artigo 60(3) refere-se para tais operações às normas internacionais geralmente adotadas, e a IMO em sua Resolução A.672 (16) fornece normas para o desmantelamento de ilhas artificiais.

Esse problema se apresenta principalmente para as plataformas petrolíferas fixas ou submersíveis, nas quais somente a parte superior é removida durante as operações de desmantelamento parcial devido ao custo de removê-las totalmente. Dada a profundidade dos campos petrolíferos do Brasil, esse problema parece

34 Esta última obrigação gerou o Programa das Nações Unidas para o Meio Ambiente - PNUE. Ver: sítio web da UNEP. Disponível em: <http://www.unep.org>. Acesso em 25 de agosto de 2016. 
não se apresentar no momento, pois as estruturas mais utilizadas são unicamente semissubmersíveis e móveis.

Com o objetivo de restaurar a liberdade de navegação, segundo o ponto de vista aqui adotado, o problema permanece por completo, pois se, por um lado, a liberdade de circulação é recuperada no momento do desmantelamento parcial das estruturas, por outro lado, o dano à outra liberdade é sustentado: o do acesso por todos aos recursos que não estão sujeitos a uma apropriação exclusiva pelos Estados costeiros sobre sua plataforma continental (artigo 77 da CMB). Aqui se refere à coluna de água que normalmente não é sujeita à exploração exclusiva pelo Estado costeiro. O fato de o Estado costeiro deixar uma estrutura permanente depois do desmantelamento das operações petrolíferas pode afetar o desfrute do mar pelos outros (i.e. submarino, pesca, etc.).

Precisa-se mencionar também que o Estado costeiro tem um interesse limitado na remoção destas instalações, visto que o custo de tal operação afeta diretamente os ganhos obtidos pelas empresas de petróleo e, portanto, afeta também as taxas cobradas pelo Estado. Talvez isso ilustre uma antiga função do mar: a de ser um "depósito de lixo".

No entanto, o impacto desse desmantelamento parcial na opinião pública, como no caso da plataforma Brent-Spar, é suscetível de alterar a situação nesse nível. ${ }^{35}$

\section{Regras relativas à cooperação científica entre Estados}

A ideia de cooperação entre Estados para a proteção do domínio marítimo é o resultado do desejo dos países em desenvolvimento de participar, bem como os países industrializados, das atividades marítimas e, assim, obter assistência em investigação científica e tecnológica.

O artigo 200 da CMB cria o princípio do dever de informação por parte dos Estados sobre suas pesquisas no setor marítimo por meio da IMO. O artigo 201 reforça a obrigação de comunicação a respeito da poluição para o estabelecimento de normas internacionais.

35 Le Monde, Paris, p. 4, 13 juillet 1995. Le Monde, Paris, p. 19, 20 octobre 1995. Le Monde, Paris, p. 14, 23 octobre 1995. Le Monde, Paris, p. 2027, octobre 1995. Guardian Weekly, p. 7, 8 février 1998. Le Point, Paris, no 1328, 28 février 1998. 
Os artigos 202 e 203 são os que, principalmente, estabelecem o dever dos países industrializados de ajudar os países em desenvolvimento, especialmente nas áreas de cooperação para a proteção do meio ambiente.

Um exemplo notável de cooperação pode ser citado no caso da Noruega, por meio da Fundação PETRAD 36 que promove a cultura da produção de petróleo no mar. A PETRAD estabeleceu um programa modelo para a operação e administração de petróleo, em cooperação com a Agência Internacional do Desenvolvimento. Por meio de seus seminários sobre "política de petróleo e de gestão" e sobre "gestão de operações petrolíferas", a Fundação dissemina conhecimento (norueguês) em assuntos tão diversos, como a regulamentação da segurança, a gestão de recursos, a promoção de normas de proteção, a estratégia energética ambiental, etc. Através desse trabalho de conscientização da cultura da exploração petrolífera, o objetivo não é somente desenvolver um conhecimento, mas também obter uma uniformização das regras aplicavéis.

Como requerido pela $\mathrm{CMB}$, o objetivo final é o bom gerenciamento dos recursos pelo Estado costeiro, mas também a disseminação dos padrões noruegueses que têm como efeito tornar as empresas norueguesas mais competitivas.

O Brasil não parece ter criado um órgão equivalente à fundação norueguesa PETRAD, mas sua empresa de economia mista PETROBRAS, que desenvolve vários programas de proteção ao meio ambiente em relação à: Política de Segurança, Meio Ambiente e Saúde; Mudanças do Clima; Recursos Hídricos; Biodiversidade; Segurança Operacional e Licenciamento Ambiental com base na cooperação internacional e em alguns casos marítimos. ${ }^{37}$

Conclusão da seção I

A análise fornecida anteriormente leva a concluir que o verdadeiro critério de diferenciação entre o regime das áreas criadas pelo Direito do Mar é baseado

36 PETRAD. Disponível em: <http://www.petrad.no/about-us>. Acesso em: 25 de agosto 2016.

37 PETROBRÁS. Disponível em: <http://www.petrobras.com.br/pt/sociedade-e-meio-ambiente/meio-ambiente>. Acesso em: 25 de agosto 2016. 
não sobre as características físicas ou geográficas dessas áreas, mas provém na verdade da diversidade das utilizações do mar.

Quando o benefício é inesgotável, o mar é livre. Essa qualidade corresponde ao Direito do Mar como meio de comunicação e, nesse caso, o princípio da liberdade permanece vivo.

Essa liberdade se extingue a partir do momento em que o recurso é sujeito à extinção. É o caso dos recursos oferecidos pelo mar que, para desfrutá-los, devese ter o uso exclusivo e poder de se apropriar dos mesmos. Isso levou o autor M. Remond a declarar que "o regime de propriedade do mar como um reservatório de riquezas se opõe ao regime do mar como um meio de comunicação, que permanece sujeito ao princípio da liberdade." ${ }^{38}$

\section{A questão é saber se existe compatibilidade entre as duas funções do mar}

A apropriação supõe, por um lado, que aquele que a realiza tem uma série de habilidades e, por outro lado, a coexistência das duas funções pressupõe que os limites de cada uma sejam especificados. A partir deste ponto, o Direito do Mar não assume somente o papel tradicional de assegurar o respeito da liberdade, mas, além disso, tem que assegurar o equilíbrio entre ambas as formas de uso.

Poder-se-ia então que a Convenção de 1958 ou CMB é precisamente o meio para esta ambição, colocando como um corolário da propriedade exclusiva de seus recursos finitos, um dever do Estado de regular, monitorar e controlar os espaços explorados. Mais do que o princípio da apropriação dos recursos finitos, o princípio diretor de responsabilização do Estado pode ser, na realidade, a verdadeira revolução e contribuição ao Direito do Mar.

Embora se encontre no campo do Direito Internacional Público, em que todos sabem que obrigar um Estado a fazer algo é difícil, não há dúvidas que o papel da ONU na comunidade internacional confere ao Direito do Mar um valor significativo. Continuando essa análise, precisa-se examinar agora como os Estados cumprem esta responsabilidade que lhes é dada.

38 REMOND-GOUILLOU Martine. L'exploitation petrolière en mer et le droit. Paris: Éditions Technip, 1970, p. 179. 


\section{SEÇÃO II. A IMPLANTAÇÃO DAS PLATAFORMAS PETROLÍFERAS À LUZ DO DIREITO DO PETRÓLEO DO ESTADO COSTEIRO}

O interesse desta seção é de destacar a maneira como os direitos e obrigações concedidos aos Estados costeiros pelo Direito do Mar são implementados por eles na sua legislação nacional. Isso também ajudará a esclarecer a atribuição de responsabilidade da exploração de petróleo no mar. Muitos países dispõem de uma legislação no que diz respeito à exploração e ao aproveitamento dos recursos petrolíferos, por meio da regulamentação das atividades de mineração, em geral ou, então, por meio de uma legislação específica, como nos seguintes casos:

- França: Lei de 30 de dezembro de 1968, relativa à exploração da plataforma continental e da exploração de seus recursos naturais. ${ }^{39}$

- Reino Unido: Lei "Continental Shelf Act 1964"40 e "Petroleum Act 1998". ${ }^{41}$

- Brasil: Lei no $9.478^{42}$ e Lei n¹2.351 (Partilha de Produção). ${ }^{43}$

- Noruega: Decreto real sobre a Plataforma Continental, de 31 de maio de 1963, e sobre a exploração e o aproveitamento, Ato de 21 de junho de $1963 .{ }^{44}$

39 Lei $n^{\circ}$ 68-1181 do 30/12/1968 em respeito à prospecção da plataforma continental e a exploração de seus recursos naturais. Disponível em: <https://www.legifrance.gouv.fr/ affichTexte.do?cidTexte=JORFTEXT 000000317510>. Acesso em: 25 de agosto de 2016.

40 Continental Shelf Act 1964. United Kingdom. Disponível em: <http://www.legislation. gov.uk/ukpga/1964/29/contents>. Acesso em: 25 de agosto de 2016.

41 Petroleum Act 1998. United Kingdom. Disponível em: <http://www.legislation.gov.uk/ ukpga/1998/17/contents>. Acesso em: 25 de agosto de 2016.

42 Lei 9.478/1997 de 06/08/1997. Dispõe sobre a política nacional, as atividades relativas ao monopólio do petróleo, institui o conselho nacional de política energética e a agência nacional do petróleo (ANP) e fornece outras providências. Disponível em: <http://legislacao. planalto.gov.br/legisla/legislacao.nsf/b110756561 cd26fd03256ff500612662/15e4f3f2e32 b132e032569fa006afb8b?OpenDocument>. Acesso em: 25 de agosto de 2016.

43 Lei no 12.351, de 22/12/2010. Dispõe sobre a exploração e a produção de petróleo, de gás natural e de outros hidrocarbonetos fluidos, sob o regime de partilha de produção, em áreas do pré-sal e em áreas estratégicas; cria o Fundo Social - FS e dispõe sobre sua estrutura e fontes de recursos; altera dispositivos da Lei no 9.478, de 6 de agosto de 1997; e dá outras providências. Disponível em: <www.planalto.gov.br/ccivil_03/_Ato20072010/2010/Lei/L12351.htm>. Acesso em: 25 de agosto de 2016.

44 Norwegian Petroleum Directorate. Act 29 November 1996 No. 72 relating to petroleum activities. Last amended by Act 24 June 2011, n 38. Disponível em: <www.npd.no/en/Regulations/Acts/Petroleum-activities-act/\#Section\%209-4>. Acesso em: 25 de agosto de 2016. 


\section{A legislação brasileira ${ }^{45}$}

O artigo 20 da Constituição da República Federativa do Brasil (1988) ${ }^{46}$ reserva à União Federal a propriedade dos recursos naturais da plataforma continental e da ZEE. O regime geral das atividades petrolíferas é regulado pela Lei no 9.478 de 6 de agosto de $1997,{ }^{47}$ que dispõe sobre a política energética nacional e outras atividades relacionadas ao monopólio do petróleo. Essa política afirma que a União Federal tem o monopólio da exploração e do aproveitamento de recursos petrolíferos que podem, contudo, ser objeto de concessões. Visto que o inventário não é exaustivo, as disposições relativas ao meio ambiente resultantes da Lei $n^{\circ} 6.938$, de 31 de agosto de 1981 sobre a política ambiental nacional, ${ }^{48}$ também são adicionadas.

Os modelos de outorga adotados no Brasil são reflexos da atual estrutura político-econômica do país e dos seus desdobramentos. O regime jurídicoregulatório define a exploração da matriz energética, o petróleo do pré-sal, como peça fundamental para o desenvolvimento econômico-social e sustentável da nação ${ }^{49}$, caracterizando o novo marco regulatório.

Em 2010 o Brasil passou a adotar um regime regulador misto que, além da exploração e da produção de petróleo e gás referentes ao pré-sal, incluiu outras áreas consideradas estratégicas.

45 A maior parte desta descrição da legislação brasileira foi feita com ajuda do relatório da Divisão de legislação comparada da direção da iniciativa parlamentar e das delegações, Senado - França (Division de législation comparée de la direction de l'initiative parlementaire et des délégations, Sénat-France), Note sur "L'exploration et l'exploitation pétrolières en mer.", Jan. 2013. Disponível em: < www.senat.fr/lc/lc230/lc230.pdf>. Acesso em: 25 de agosto de 2016.

46 Constituição da República Federativa do Brasil. Disponível em: <www.planalto.gov.br/ ccivil_03/ constituicao/constituicao.htm> <www.senado.gov.br/legislacao/const/con1988/ CON1988_13.07.2010/art_20_.shtm>. Acesso em: 25 de agosto de 2016.

47 Dispõe sobre a política energética nacional, as atividades relativas ao monopólio do petróleo, institui o Conselho Nacional de Política Energética e a Agência Nacional do Petróleo e dá outras providências. Disponível em: <http://www.planalto.gov.br/ccivil_03/leis/l9478. htm>. Acesso em: 25 de agosto de 2016.

48 Lei n⿳ 6.938, de 31/08/1981. Dispõe sobre a Política Nacional do Meio Ambiente, seus fins e mecanismos de formulação e aplicação. Disponível em: <www.planalto.gov.br/ ccivil_03/leis/l6938.htm>. Acesso em: 25 de agosto de 2016.

49 As estimativas de reservas para o pré-sal brasileiro indicam um potencial de 70 a 100 biIhões de barris de óleo equivalente - BOE (somatório de petróleo e gás natural). 
Os principais modelos adotados de contrato para exploração e produção de petróleo e gás no Brasil são: i) a concessão, com base na Lei n. ${ }^{\circ}$ 9.478, de 6 de agosto de 1997 (Lei do Petróleo) ${ }^{50}$, ii) o contrato de partilha de produção, determinado pela Lei n. ${ }^{\circ} 12.351$, de 22 de dezembro de $2010^{51}$, para as áreas do polígono do pré-sal ${ }^{52}$ e outras estratégicas ${ }^{53}$, e iii) a cessão onerosa, instituída pela Lei $n^{0} 12.276$, de 30 de junho de $2010^{54}$, criada exclusivamente para a Petrobrás.

\section{As autoridades responsáveis pela emissão de títulos ou autorização}

- A Agência Nacional do Petróleo, Gás Natural e Biocombustíveis (ANP) é uma autoridade administrativa federal independente responsável pela regulação, celebração de contratos e controle do setor de petróleo, em virtude da Lei n 9.478, de 1997. Ela gerencia todos os dados sobre as bacias sedimentares brasileiras. A ANP prepara concursos (licitações) para a exploração, desenvolvimento e produção de petróleo, celebra contratos com os concessionários e também controla a execução dos contratos. Todos os direitos de prospecção e exploração de petróleo concedidos por lei para a União Federal são regulados pela ANP, e estão relacionados ao território, ao mar territorial, à plataforma continental ou à zona econômica exclusiva.

- O Conselho Nacional de Política Energética (CNPE) determina os objetivos da política energética do país e da Agência Nacional de Petróleo, Gás Natural e Bicombustível(ANP) quedispõedehabilidadestécnicasparaimplementá-las. Presidido pelo Ministro da Energia, o CNPE vincula-se ao Presidente da República e propõe 50 Disponível em: <http://www.planalto.gov.br/ccivil_03/leis/L9478.htm>. Acesso em: 25 de agosto de 2016.

51 Disponível em: <http://www.planalto.gov.br/ccivil_03/_Ato2007-2010/2010/Lei/L12351. htm>. Acesso em: 25 de agosto de 2016.

52 Art. $2^{\circ}$ inciso IV, assim define - área do pré-sal: região do subsolo formada por um prisma vertical de profundidade indeterminada, com superfície poligonal definida pelas coordenadas geográficas de seus vértices estabelecidas no Anexo desta Lei, bem como outras regiões que venham a ser delimitadas em ato do Poder Executivo, de acordo com a evolução do conhecimento geológico.

53 Art. $2^{\circ}$ inciso $\mathbf{V}$, assim define: área estratégica: região de interesse para o desenvolvimento nacional, delimitada em ato do Poder Executivo, caracterizada pelo baixo risco exploratório e elevado potencial de produção de petróleo, de gás natural e de outros hidrocarbonetos fluidos.

54 Disponível em: <http://www.planalto.gov.br/ccivil_03/_ato2007-2010/2010/Lei/L12276. htm>. Acesso em: 25 de agosto de 2016. 
diretrizes da Política Nacional de Energia. Ademais, o Ministro da Energia propõe o ritmo das assinaturas de contratos de "blocos" submetidos ao regime de partilha de produção (ver a seguir), em face da política energética e do desenvolvimento da capacidade da indústria nacional para fornecer bens e serviços.

- O Ministério de Minas e Energia é responsável pelo planejamento da política de aprovisionamento de petróleo; de propor ao CNPE, após consulta à ANP a determinação de "blocos" projetados para serem um contrato de concessão ou de partilha de produção.

\section{Procedimento de atribuição de títulos ou autorizações}

Disposições gerais

O regime de concessão ${ }^{55}$

Nos termos do artigo 24 da Lei no 9.478, de 6 de agosto de 1997, o contrato de concessão tem duas fases: exploração, incluindo a avaliação da descoberta; e a produção, incluindo o desenvolvimento de depósitos. Cada concessão é para um bloco determinado. Os planos de desenvolvimento da produção estão sujeitos à aprovação da ANP, que emite sua decisão no prazo de 180 dias após o período de transmissão, depois que eles forem aprovados. O óleo que é extraído pertence ao concessionário. A concessão é atribuída numa base competitiva após um concurso (licitação).

\section{O regime de Partilha de Produção}

O regime de partilha de produção é definido pela Lei $n^{\circ} 12.351$, de 22 de dezembro de 2010. A Lei de partilha de produção é um regime de exploração e produção de petróleo, de gás natural e de outros hidrocarbonetos fluidos no qual 55 Para uma análise crítica do regime de concessão no Brasil ver: MACHADO Alexandre, SALEME Edson Ricardo. Instrumentos de outorga e o contrato de concessão no upstream brasileiro: modelos e procedimentos aplicados na $11^{\text {a }}$ rodada de licitações de petróleo e gás. Conselho Nacional de Pesquisa e Pós-graduação em Direito (CONPEDI), 2013, GT8. Direito e Administração Pública. Disponível em: <http://www.publicadireito.com.br/ artigos/?cod=426ea2897becd895 > . Acesso em: 25 de agosto de 2016. 
o contratado exerce, por sua conta e risco, as atividades de exploração, avaliação, desenvolvimento e produção e, em caso de descoberta comercial, adquire o direito à apropriação do custo em óleo, do volume da produção correspondente aos royalties devidos, bem como de parcela do excedente em óleo, na proporção, condições e prazos estabelecidos em contrato (Art. $2^{\circ}$, inciso I).

\section{Disposições ambientais}

A Seção 225 da Constituição Federal do Brasil estabelece o direito ao meio ambiente ecologicamente equilibrado, bens de uso comum do povo e essencial à qualidade de vida, que as autoridades públicas têm o dever de defender e preservar para as gerações presentes e futuras.

A Lei n 6.938, de 31 de agosto de 1981, prevê que todas as atividades «potencialmente poluidoras» estão sujeitas à autorização (licenciamento) ambiental. ${ }^{56}$

O Decreto n 99.274 de 6 de junho de 1990 e o Decreto $n^{\circ} 422$ de 26 de outubro de 2011 especificam as regras aplicáveis em relação ao licenciamento. A construção, a instalação, a ampliação e a operação de instalações cujas atividades utilizam recursos ambientais, que são realmente ou potencialmente poluidores, estão sujeitas a um processo de autorização ambiental. Isso se baseia na obtenção de um estudo de impacto e na obtenção de autorizações:

- "antes da exploração petrolífera", com validade por mais de 5 anos, o estudo é emitido na fase preliminar da atividade de planejamento, o que indica as obrigações básicas a serem cumpridas para a localização e instalação;

- "instalação ou durante a instalação da infraestrutura para a exploração e produção petrolíferas", com validade até 6 anos, o que permite o início da implementação;

- E "operacional ou durante a exploração e produção petrolíferas", com validade até 10 anos, o que torna possível, após as verificações necessárias, o início da atividade e da função do equipamento de controle de poluição.

56 Lei n⿳0 6.938, de 31/08/1981. Dispõe sobre a Política Nacional do Meio Ambiente, seus fins e mecanismos de formulação e aplicação, e dá outras providências. Disponível em: <http://www.planalto.gov.br/ccivil_03/leis/l6938.htm>. Acesso em: 25 de agosto de 2016. 
Parece importante citar o conjunto de leis applicáveis às atividades petrolíferas, dado que estas leis têm como objetivo regular a poluição, que é um risco associado à exploração petrolífera:

- Lei n 9.605 de 12 de fevereiro de $1998^{57}$ sobre as ações criminais aplicáveis contra o poluidor (como no caso Chevron já citado).

- Lei $n^{\circ}$ 9.966, de 28 de abril de $2000^{58}$ e o decreto $n^{\circ} 4.136$, de 20 de fevereiro de $2002,{ }^{59}$ que contém disposições que visam especificamente a quaisquer instalações de petróleo no mar.

- Regulamento Inter-Ministerial n 198, de 5 de abril de 2012 sobre a avaliação ambiental das zonas sedimentares. Este fornece, por sua vez, uma "Avaliação ambiental de áreas sedimentares" (Avaliação Ambiental de Áreas Sedimentares, AAAS) que será realizada juntamente com os ministérios das Minas e Energia, e do Meio Ambiente.

\section{Disposições financeiras}

A Seção 20 da Constituição Federal do Brasil determina que o governo do Estado, municípios e órgãos do governo federal têm, nos termos previstos pela lei, interesse no resultado da exploração de petróleo em seu território. As obrigações financeiras do concessionário ou do contratante (no caso de Partilha de Produção) dependem do contrato assinado por eles.

Concluindo esta breve apresentação do sistema de atribuição de licenças de prospeção e produção de petróleo no Brasil, parece muito claro que o Brasil está regulamentando todas as atividades que ocorrem na sua plataforma continental,

57 Lei no 9.605, de 12/02/1998. Dispõe sobre as sanções penais e administrativas derivadas de condutas e atividades lesivas ao meio ambiente. Disponível em: <http://www. planalto.gov.br/ccivil_03/leis/19605.htm>. Acesso em: 25 de agosto de 2016.

58 Dispõe sobre a prevenção, o controle e a fiscalização da poluição causada por lançamento de óleo e outras substâncias nocivas ou perigosas em águas sob jurisdição nacional. Disponível em: <http://www.planalto.gov.br/ccivil_03/leis/L9966.htm>. Acesso em: 25 de agosto de 2016.

59 Dispõe sobre a especificação das sanções aplicáveis às infrações, às regras de prevenção, controle e fiscalização da poluição causada por lançamento de óleo e outras substâncias nocivas ou perigosas em águas sob jurisdição nacional, prevista na Lei n 9.966. Disponível em: <http://www.planalto.gov.br/ccivil_03/decreto/2002/D4136.htm>. Acesso em: 25 de agosto de 2016. 
fazendo uso de sua soberania em conformidade com os deveres e as obrigações decorrentes do Direito do Mar. Isso ilustra mais uma vez a relação entre a atividade petrolífera no mar e o Estado costeiro.

\section{A legislação norueguesa}

A respeito do funcionamento do sistema norueguês é importante distinguir duas fases. Para a empresa que deseja trabalhar na plataforma continental norueguesa, o primeiro passo é obter uma licença, ou melhor, ter interesse em obter uma licença. Graças a isso, o Estado norueguês autoriza a empresa petrolífera a dirigir operações preestabelecidas em uma área específica da plataforma continental. Esse é um passo necessário, porém não suficiente para o cumprimento efetivo da produção de petróleo. Uma vez a licença concedida à empresa ou grupo de empresas, será necessário também que a empresa obtenha duas permissões distintas das autoridades norueguesas.

\section{Validação da licença / concessão}

Existem dois tipos de licença / concessão em direito norueguês:

- Licença / concessão de exploração.

- Licença / concessão de produção.

Os dois tipos de licença são concedidos pelo «Ministro do Petróleo e Energia». Como os nomes sugerem, a primeira licença / concessão confere apenas direitos para fazer a prospeção de petróleo, enquanto a segunda licença / concessão permite a produção de óleo.

Tal como indicado no capítulo 2 Seção 2-1 e 2-2 da Lei do Petróleo (PA), ${ }^{60}$ a licença de exploração não garante ao seu titular o direito exclusivo de prospecção de petróleo na área, assim como não tem direitos sobre esta licença de preferência 60 Norwegian Petroleum Act 29 November 1996 No. 72 relating to petroleum activities. Ver: definição de Petroleum activity" in Seção 2 da lei. Disponível em: <http://www.npd. no/en/Regulations/Acts/Petroleum-activities-act/\#Section\%209-4>. Acesso em: 25 de agosto de 2016. 
para a obtenção de uma possível licença de produção se as pesquisas são positivas. Por isso, o Estado norueguês conserva o direito de escolher os seus parceiros para as operações de produção de petróleo futuras. Além disso, como se observará, o resultado da pesquisa realizada pela empresa caindo em domínio público obriga a empresa a reportar à Direção do Petróleo da Noruega.

Essa liberdade do Estado é ainda maior em relação à obtenção de uma licença de produção. Nesse caso o Ministério do Petróleo e Energia da Noruega é completamente livre para determinar as partes da licença, a participação percentual da licença e, especialmente, do operador. Isso está implícito na seção 3-7 da PA, que informa que o operador deve ser aprovado pelo Ministério. ${ }^{61}$ Essa escolha é totalmente discricionária por parte do Estado, que tomará sua decisão por meio de um Conselho ("King in Concil") e após consulta às autoridades competentes, entre outros, à Direção do Petróleo da Noruega (NDP).

A Seção 10 do decreto sobre as atividades petrolíferas ${ }^{62}$ especifica quais são os critérios utilizados pelo Estado na sua escolha. É feita referência, nomeadamente, à competência técnica, às experiências passadas que o Estado teve com o recorrente no processo de atribuição de licença. A Seção 1-6 do PetroleumAct define a licença e o operador e a Seção 3-7 especifica a mudança de regime de operação.

Esse intervencionismo bastante importante do Estado norueguês não é encontrado em todas as legislações de petróleo. Diversas legislações deixam as companhias livres para escolher o operador, assim que seus parceiros nas empresas de licenciamento e sua porcentagem de participação.

\section{Descrição da legislação norueguesa}

Ao aderir à licença, a empresa aceita estar sujeita à legislação de petróleo norueguesa, mas também a ratificar o "Acordo de exploração conjunta das

61 Norwegian Petroleum Act 29 November 1996 No. 72 relating to petroleum activities. Ver Seção 3 da Lei.

62 Regulations to Act relating to petroleum activities (Regulamento relativo às atividades petrolíferas), no 1997-06-27-653, 27 de junho de 1997. Disponível em: <http://www.npd. no/en/regulations/regulations/petroleum-activities/>. Acesso em: 25 de agosto de 2016. 
atividades petrolíferas". ${ }^{63}$ A Seção 4 -7 do Petroleum Act exige que as partes titulares de uma licença cheguem a um acordo entre elas, e que esse "acordo" seja aprovado pelo Ministro do Petróleo. Esse contrato é, em realidade, um contrato de adesão imposto às companhias contratantes de uma mesma licença pela qual elas se comprometem a cooperar de uma maneira definida precisa. O processo pode ser percebido como muito autoritário, mas os resultados parecem positivos. As empresas são obrigadas a concordar. As relações e os papéis de cada um são claramente nela definidos. Mas do que tudo, isso permite ao Estado controlar estritamente as atividades petrolíferas.

O preço da licença é de fato constituído pelo investimento que deverá ser feito pelas empresas para realizar a produção. Esse investimento, que pode ser colossal, é baseado no percentual de participação de cada empresa na licença. Esse percentual também determina a distribuição dos frutos da produção de petróleo. O Estado norueguês pode ter ações em licenças em conformidade com a Seção 3-6 da Lei do petróleo. O que, aliás, ele já fez no passado, possuindo partes até $51 \%$ em algumas licenças. Atualmente isso não é mais o caso, devido ao enorme investimento que essa participação vem tendo, dado o número de instalações no Mar do Norte. $O$ decreto relativo à gestão de recursos ${ }^{64}$ determina no capítulo 5 as taxas de ajuste; e, no capítulo 7, a natureza das relações que devem existir entre a licença e o Estado. O capítulo 7 salienta a obrigação de informação do Estado pela licença sobre a maneira pela qual as operações são conduzidas e da sua conformidade com o que foi planejado com o plano de desenvolvimento.

\section{Conformidade ao direito europeu}

A Noruega, como parte do Espaço Econômico Europeu (EEE) e da Associação Europeia de Comércio Livre (EFTA), está sujeita a certas partes do Direito Comunitário. É difícil dizer se a legislação norueguesa está de acordo com o Direito Comunitário.

63 Para um exemplo de Acordo Conjunto Operacional das atividades petrolíferas, ver: <http:// www.ampla.org/documents/item/164>. Acesso em: 25 de agosto de 2016.

64 Ver nota de página n45: Constituição da República Federativa do Brasil. Disponível em: <www.planalto.gov.br/ccivil_03/constituicao/constituicao.htm><www.senado.gov.br/ legislacao/const/con1988/CON1988_13.07.2010/art_20_.shtm>. Acesso em: 25 de agosto de 2016. 
Transportes e energia são áreas fundamentais de competência da União Europeia e, nesse nível, a Comissão Européia dispõe de um papel muito importante.

Em duas decisões sobre os processos de adjudicação de contratos nos setores da água, energia, transportes e telecomunicações, a Comissão Européia considerou que a regulamentação dos Países Baixos e do Reino Unido não estava conforme o Direito Comunitário. ${ }^{65}$ Desde então, as regras europeias sobre a concorrência foram se expandindo. O objetivo desta diretiva é favorecer a concorrência entre os adjudicatários para a licença de exploração de petróleo, mas também limitar o efeito anticompetitivo indireto projetado para encorajar o adjudicatário a se fornecer no país da licença.

O direito europeu deixa a porta aberta para uma série de exceções que podem ser explicadas pelo fato de que a indústria do petróleo é uma área que afeta a política energética de um país. ${ }^{66}$ Mas a contribuição do Direito Comunitário não é limitada apenas a estas orientações sobre a concorrência no domínio do licenciamento. Existem muitas disposições europeias sobre a relação entre as atividades de petróleo e de pesca, a poluição, o desmantelamento das instalações. As políticas europeias em matéria de recursos energéticos desempenham um papel importante no setor de produção de petróleo offshore.

\section{A validação do "PDO" e a atribuição do "Consent"}

Esses procedimentos correspondem a duas preocupações do Estado norueguês: segurança em sentido amplo (de pessoas, equipamentos, prevenção da poluição) e gestão de recursos. O importante é que essas preocupações sejam representadas por entidades distintas e independentes, pois a gestão econômica dos recursos poderia ofuscar as considerações de segurança. Por esta razão, é necessário que duas formalidades sejam impostas sobre as licenças antes de entrar na fase de produção real.

65 Ambos os casos foram iniciados pela demanda dos Estados interessados a considerar o seu direito interno em conformidade com a Directiva 90/531 e, em particular, os requisitos do artigo $3^{\circ}$ que permite condições específicas de certas práticas menos competitivas.

66 Um exemplo seria a Directiva de 30 de Maio de 1994, que prevê no seu artigo 13 que os artigos 3 e 5 não se aplicam na Dinamarca, cuja plataforma continental foi objeto de uma concessão exclusiva ao grupo APM $\varnothing L L E R$. 


\section{O plano de desenvolvimento (PDO)}

As Seções 4-2 até 4-6 do Petroleum $A c t^{67}$ impõem àquele que dispõe da licença de apresentar um plano de desenvolvimento para as diversas operações, tais como a produção de óleo, as unidades de armazenamento, a perfuração, etc. O plano de desenvolvimento de licença permite às partes titulares da licença de explicar às autoridades de maneira exaustiva como eles vão desenvolver a concessão. As decisões tomadas nesse nível refletem a cultura do Estado costeiro e seu desejo de preservar os seus recursos petrolíferos.

A decisão é tomada em nível ministerial pelo governo reunido em "King in Concil (Conselho do Estado e do rei)", mas ao contrário do que acontece com a licença, quando o investimento previsto é de menos de 5 bilhões de coroas, a decisão será tomada por uma delegação composta pelo Parlamento em favor do governo. O parlamento é o único competente para aprovar o plano de desenvolvimento.

Um exemplo bastante significativo da função desse plano é ilustrado por uma decisão do Ministério sobre a instalação "Troll", operada pela companhia Shell. Durante a apresentação do plano, a empresa apenas planejava a extração de gás, porque seus geólogos acreditavam que não havia recursos petrolíferos nesse campo para justificar uma planta de extração de óleo. Os geólogos da administração de petróleo norueguês não chegaram às mesmas conclusões que a companhia petrolífera, e o governo decidiu rejeitar o plano proposto pela Shell. Assim, a empresa propôs um novo plano, no qual apresentou as instalações e as pesquisas técnicas para destacar recursos potenciais de petróleo. Isso demonstra a função de desenvolvimento de gestão de planos de recursos. Para completar nossa ilustração, convém mencionar que, de fato, grandes quantidades de petróleo foram descobertas posteriormente naquele campo.

67 Norwegian Petroleum Act 29 de novembro de $1996 n^{\circ} 72$ relating to petroleum activities. Last amended by Act 24 June 2011, n 38. Disponível em: <www.npd.no/en/Regulations/Acts/Petroleum-activities-act/\#Section\%209-4>. Acesso em: 25 de agosto de 2016. Inclui normas técnicas de perfuração usadas (custo de construção) sobre a velocidade de operação e de bombeamento fornecidos. 
Outra justificativa para esses planos de desenvolvimento é que eles permitem ao Estado costeiro de manter o controle sobre o desenvolvimento das áreas exploradas pelo detentor da licença. Seja porque o Estado Costeiro dispõe de partes na licença (como co-empresário então), seja porque o Estado costeiro é de qualquer maneira indiretamente parte integrante desta empresa através dos impostos que ele cobrará sobre a produção e, portanto, a rentabilidade da operação.

\section{A aceitação (Consent)}

As Seções 9-5 e 9-6 do Petroleum Act ${ }^{68}$ obriga titulares de licenças a possuírem as qualificações exigidas pelas regras norueguesas em matéria de segurança e proteção ambiental. A Seção 15 do Decreto sobre a segurança das operações de petróleo requer obtenção de consentimento antes de qualquer operação de perfuração além de 25 metros.

O "consent" é em realidade a permissão para obter uma licença (muitas vezes para um grupo de empresas) para realizar atividades de produção de petróleo na área definida pela licença, utilizando instalações consideradas como compatíveis com a segurança do meio ambiente.

O ministério responsável pela questão da segurança do meio ambiente e das condições de trabalho na indústria norueguesa é o ministério "do governo local e do trabalho." No entanto, na prática, este ministério delegou este poder para a Direção Norueguesa de Petróleo (NPD), que possui tanto o poder para conceder autorizações e para removê-las.

Conforme a exigência feita pela Seção 15 do Decreto, das licenças terem o "consent", a retirada do "consent" significa a cessação imediata das operações de produção pelo menos temporariamente.

Para a atribuição do "consent", os técnicos do NPD fazem vários testes e controles em relação a:

68 MINISTRY OF PETROLEUM AND ENERGY. Norwegian Petroleum Act 29 de novembro de $1996 n^{\circ} 72$ relating to petroleum activities. Last amended by Act 24 June 2011, $n^{\circ} 38$. Disponível em: <www.npd.no/en/Regulations/Acts/Petroleum-activities-act/\#Section\%20 9-4>. Acesso em: 25 de agosto de 2016. 
- Exames de estruturas e planos de instalação.

- Controle por meio de auditoria de gestão de risco por parte do operador.

- Análise dos procedimentos de segurança.

As condições para a atribuição do "consent" variam consideravelmente de um estabelecimento para outro por causa da diversidade das instalações. Pode-se, no entanto, propor a seguinte classificação:

- Para instalação fixa, na maior parte do tempo, haverá uma estrutura construída especificamente para o lugar para o qual ela se destina. O NDP controlará a fase de construção, impondo seus padrões e realizando vários controles. Esses controles são acoplados com sanções penais em caso de negligência grave por parte dos responsáveis das operações de petróleo que eles dirigem ${ }^{69}$.

- Para uma instalação móvel construída na Noruega, mas cujo destino não é necessariamente a plataforma continental norueguesa, o NPD vai intervir para monitorar o cumprimento de suas normas.

- Para uma instalação móvel construída no estrangeiro, mas cujo destino é a plataforma continental norueguesa, o NDP vai intervir nos estaleiros estrangeiros para operar os controles sobre a construção da estrutura em conformidade com suas normas. O NPD efetua controles técnicos sobre as instalações, tal como auditorias da empresa e do local de construção, com a mesma estratégia de vincular o contratante principal ao subcontratante por meio da questão de segurança.

- Da mesma forma, qualquer planta móvel construída anteriormente que fosse operar na plataforma continental norueguesa deverá obter o "consent". A 69 Um exemplo da aplicação desta disposição para a construção de uma instalação fixa foi dado recentemente no caso SLEIPNER. Ver: http://home.versatel.nl/the_sims/rig/sleipnera.html. A construção ostensivamente defeituosa de uma plataforma fixa causou seu naufrágio durante as operações de água de lastro na saída do porto de Stavanger. Responsabilidades criminais têm sido procuradas nas duas empresas: na do construtor da instalação e na companhia petrolífera que tinha efetuado a encomenda. Subentende-se que a segunda empresa não pode se descarregar completamente sobre o fabricante-projetista e continua sendo a responsável. Mesmo se o Procurador « statsadvokat » retirou as acusações, elas foram, no entanto, um sério aviso e um incentivo para que as empresas petrolíferas se impliquem mais nas suas obras, em vez de simplesmente delegá-las, visto que os patrões da empresa petrolífera também estão na linha de mira das ações judiciais. 
ligação com as atividades petrolíferas na plataforma continental norueguesa é o suficiente para que o NPD considere necessária a aplicação de suas normas de segurança. $\mathrm{O}$ "consent" é um tipo de inspeção técnica que somente o NDP está apto a executar de acordo com seus próprios critérios. Nesse caso específico, se está distante de qualquer norma internacional. Mesmo que o decreto relativo à segurança reconheça o valor dos controles das sociedades de classificação marítima, controles que "podem ser usados como base", eles não podem de forma alguma permitir sozinhos a obtenção de consentimento.

Nesse nível existe também uma complementaridade entre a administração marítima e a Direção de Petróleo na Noruega. Uma instalação móvel que vai trabalhar ou atuar na Noruega deve inicialmente obter o certificado da autoridade marítima. Também é necessário obter o "consent" da Direção do Petróleo quando se pretende realizar uma atividade petrolífera específica.

A natureza jurídica das autorizações merece esclarecimento: o NPD não assume qualquer responsabilidade pelo cumprimento das suas exigências; seus representantes insistem que o consentimento não é uma "aprovação", mas apenas uma autorização por meio da qual a administração norueguesa do petróleo diz não fazer nenhuma objeção a uma determinada instalação de operar na plataforma norueguesa.

Geralmente as decisões do NDP são decisões administrativas sujeitas a recursos. 0 organismo responsável pelo tratamento do pedido depende da natureza da decisão em causa; no caso de uma decisão relativa à gestão dos recursos, o Ministério do Petróleo e da Energia terá jurisdição. No caso de uma decisão relativa à segurança (safety), o ministério "do governo local" será a autoridade competente. ${ }^{70}$

No entanto, como as decisões do NPD possuem natureza deatos administrativos, pode-se imaginar que a responsabilidade do Estado norueguês seja procurada no caso em que a Direção Norueguesa de Petróleo tenha problemas durante sua atividade causando danos. Isso precisaria ser provado nos termos do direito

70 Dado que o ministério não dispõe de seus própios serviços técnicos para abordar as questões de segurança, ele delegou sua autoridade ao NDP. O ministério vai, por conseguinte, na maioria dos casos, atuar em conformidade com o parecer do NDP. Subentende-se que as possibilidades oferecidas pelo tal apelo, portanto, parecem escassas. 
comum da responsabilidade administrativa por uma má conduta responsável pelo dano, o que parece por definição dificilmente realizável, dado ao fato de que o NDP não tem controle das operações de construção e de segurança a bordo das instalações.

A Noruega é um dos poucos Estados que têm realizado tais controles técnicos pelos agentes de sua administração. O Reino Unido modificou o quadro legal da exploração do petróleo no mar, ${ }^{71}$ após a explosão da plataforma de "piper alfa". Atualmente, qualquer empresa petrolífera que queira operar na plataforma continental inglesa e escocesa deve submeter à aprovação um "plano de segurança" que, na verdade, é a apresentação de um programa de gestão da segurança para estas instalações. Segundo o Professor Knut Kaasen, esta mudança de posição após o acidente proporcionou uma reconciliação do Reino Unido com a legislação norueguesa sobre a segurança das instalações offshore. ${ }^{72}$

Conclusão da seção II

A primeira observação que resulta da breve apresentação das diversas legislações petrolíferas estatais confirma que as plataformas de petróleo estão sujeitas a uma atenção especial dos Estados costeiros, o que leva a se dizer que: o Estado costeiro tem um papel fundamental na ocupação do mar por plataformas petrolíferas, dada a função delas: a exploração de petróleo.

Pode-se assim concluir que existe uma diferença notável entre os navios e as plataformas petrolíferas, visto que os navios recebem aplicação exclusiva das normas do Estado de bandeira.

A segunda observação é que existem grandes diferenças na maneira precisa que cada Estado vai assumir a competência e a responsabilidade que lhe foi incumbida

71 BENTHAM, R. W. The United Kingdom Offshore Safety Regime: Before and After Piper Alpha. Journal of energy and natural resources law, v.9, $n^{\circ} 4$, p. 273, 1991. Disponível em: <http://www.tandfonline.com/doi/abs/10.1080/02646811.1991.11433727?journalCo de=rnrl20 $>$. Acesso em: 25 de agosto 2016.

72 KAASEN, Knut. Post piper alpha: some reflections on offshore safety regimes from a Norwegian perspective. Journal of energy and natural resources law, v.9, n 4, p. 281.1991. Disponível em: <http://www.tandfonline.com/doi/abs/10.1080/02646811.1991.1143372 8>. Acesso em: 25 de agosto 2016. 
pela Convenção de Montego Bay na plataforma continental. Essa observação resulta da sucinta comparação das legislações norueguesa e brasileira.

Pode-se legitimamente questionar se a lei norueguesa não teria, em certa medida, contribuído para evitar acidentes como o vazamento de petróleo na plataforma da Chevron no campo de Frade. $^{73}$

\section{CONSIDERAÇÕES FINAIS}

Este artigo tem como principal objetivo destacar relevantes aspectos intrínsecos do Direito do Mar.

Observou-se que o verdadeiro critério de diferenciação entre os regimes das áreas criadas pelo Direito do Mar provém da escassez ou da abundância de recursos marinhos cobertos pelo plano de uma área particular.

Com respeito à liberdade de explorar os recursos do mar, existe somente quando os recursos são abundantes, porém ela termina assim que os recursos ficam raros. Dois exemplos ilustram esta afirmação: a pesca na coluna de água e a extração de petróleo na plataforma continental.

A análise de direito comparado contribui paraa destacar não somente as diferenças existetes entre a Convenção Internacional sobre o Direito do Mar e sua implementação pelos diferentes países signatários, mas também salienta a diferença entre a prática adotada pelos Estados signatários a nível da aplicação desta mesma Convenção.

\section{REFERÊNCIOAS DAS FONTES CITADAS}

AGÊNCIA NACIONAL DO PETRÓLEO, GÁS NATURAL E BIOCOMBUSTÍVEIS (ANP). Investigação do incidente de vazamento de petróleo no campo de Frade - relatório final. Superintendência de segurança operacional e meio ambiente (SSM), julho de 2012. Disponível em: <http://www.anp.gov.br/?dw=61108>. Acesso em: 25 de agosto 2016.

73 Ver: Investigação do incidente de vazamento de petróleo no campo de Frade - relatório final, Agência Nacional do Petróleo, Gás natural e Biocombustíveis (ANP), Superintendência de segurança operacional e meio ambiente (SSM), julho de 2012. Disponível em: <http://www.anp.gov.br/?dw=61108>. Acesso em: 25 de agosto 2016. 
BENTHAM, R. W. The United Kingdom Offshore Safety Regime: Before and After Piper Alpha. Journal of energy and natural resources law, v.9, n 4, p. 273, 1991. Disponível em:<http:// www.tandfonline.com/doi/abs/10.1080/02646811.1991.11433727? journalCode =rnrl20 > Acesso em: 25 de agosto 2016.

BEURIER Jean-Pierre, CADENAT Philippe. Le droit de la mer dix ans après Montego-Bay. Droit maritime français, octobre 1993, n 531, p. 435.

BONASSIES Pierre. Le droit positif Français en 1994. Droit Maritime Français, n 3, 1995.

BONIFASSI Marie-Laure. Montego Bay: 30 ans après. Appropriation et exploitation des espaces maritimes : état des lieux, droit, enjeux. Centre d'Études Supérieures de la Marine, p. 30. Disponível em: <http://cesm.marine.defense.gouv.fr/content/download/3762/54304/file/ CESM\%20Montego\%20Bay-bonne\%20version.pdf>. Acesso em: 25 de agosto de 2016

BRASIL. Constituição da República Federativa do Brasil, Brasília, DF: Senado, 1988. Disponível em: <www.planalto.gov.br/ccivil_03/constituicao/constituicao.htm> Acesso em: 25 de agosto de 2016

Artigo $\mathbf{n}^{\circ}$ 20. Disponível em: www.senado.gov.br/legislacao/const/con1988/ CON1988_13.07.2010/art_20_.shtm Acesso em: 25 de agosto de 2016

Lei $n^{\circ}$ 6.938, de 31/08/1981. Dispõe sobre a Política Nacional do Meio Ambiente, seus fins e mecanismos de formulação e aplicação. Disponível em: <www.planalto.gov.br/ ccivil_03/leis/16938.htm>. Acesso em: 25 de agosto de 2016.

Lei $\mathbf{n}^{\circ}$ 9.478/1997 de 06/08/1997. Dispõe sobre a política nacional, as atividades relativas ao monopólio do petróleo, institui o conselho nacional de política energética e a agência nacional do petróleo (ANP) e fornece outras providências. Disponível em: < http:// legislacao.planalto.gov.br/legisla/legislacao.nsf/b110756561cd26fd03256ff500612662/15e4f 3f2e32b132e032569fa006afb8b?OpenDocument>. Acesso em: 25 de agosto de 2016.

. Lei $\mathbf{n}^{\circ}$ 9.605, de 12/02/1998. Dispõe sobre as sanções penais e administrativas derivadas de condutas e atividades lesivas ao meio ambiente. Disponível em: <http://www. planalto.gov.br/ccivil_03/leis//9605.htm>. Acesso em: 25 de agosto de 2016.

Lei $\mathbf{n}^{\circ}$ 9.966, de 28/04/2000. Dispõe sobre a prevenção, o controle e a fiscalização da poluição causada por lançamento de óleo e outras substâncias nocivas ou perigosas em águas sob jurisdição nacional. Disponível em: < http://www.planalto.gov.br/ccivil_03/leis/ L9966.htm>. Acesso em: 25 de agosto de 2016. 
Decreto $n^{\circ}$ 4.136, de 20/02/2002. Dispõe sobre a especificação das sanções aplicáveis às infrações, às regras de prevenção, controle e fiscalização da poluição causada por lançamento de óleo e outras substâncias nocivas ou perigosas em águas sob jurisdição nacional, prevista na Lei $n^{\circ}$ 9.966. Disponível em: <http://www.planalto.gov.br/ccivil_03/decreto/2002/D4136. htm>. Acesso em: 25 de agosto de 2016.

Lei $\mathbf{n}^{\circ}$ 12.276, de 30 de junho de 2010. Disponível em: <http://www.planalto.gov.br/ ccivil_03/_ato2007-2010/2010/Lei/L12276.htm>. Acesso em: 25 de agosto de 2016.

Lei no 12.351, de 22/12/2010. Disponível em: <www.planalto.gov.br/ccivil_03/_ Ato2007-2010/2010/Lei/L12351.htm>. Acesso em: 25 de agosto de 2016.

Lei $\mathbf{n}^{\circ} \mathbf{6 8 - 1 1 8 1}$ do 30/12/1968 em respeito à prospecção da plataforma continental e a exploração de seus recursos naturais. Disponível em: <https://www.legifrance.gouv.fr/ affichTexte.do?cidTexte=JORFTEXT000000317510>. Acesso em: 25 de agosto de 2016.

BROWN Edward Duncan. The international Law of the Sea. The American Journal of International Law, v. I, p. 445-477, Jan. 1996.

CHURCHILL Robin, LOWE Alan Vaughan. The Law of the Sea. 3 ed., Juris Publishing Inc, December 1999, p. 251.

Continental Shelf Act 1964. United Kingdom. Disponível em: < http://www.legislation.gov. uk/ukpga/1964/29/contents >. Acesso em: 25 de agosto de 2016.

GROTIUS, Hugo. Mare Liberum, 1609.

KAASEN, Knut. Post piper alpha: some reflections on offshore safety regimes from a Norwegian perspective. Journal of energy and natural resources law, v.9, n 4 , Disponível em: <http://www. tandfonline.com/doi/abs/10.1080/02646811.1991.11433728>. Acesso em: 25 de agosto 2016.

Law of The Sea Bulletin, n¹2, p. 39-40. Dezembro 1988.

MACHADO Alexandre, SALEME Edson Ricardo. Instrumentos de outorga e o contrato de concessão no upstream brasileiro: modelos e procedimentos aplicados na $11^{\text {a }}$ rodada de licitações de petróleo e gás. Conselho Nacional de Pesquisa e Pós-graduação em Direito (CONPEDI), 2013, GT8. Direitoe Administração Pública. Disponível em:<http://www.publicadireito. com.br/artigos/?cod=426ea2897becd895>. Acesso em: 25 de agosto de 2016.

MINISTRY OF PETROLEUM AND ENERGY. Petroleum Directorate. Act 29 November 1996 No. 72 relating to petroleum activities. Last amended by Act 24 June 2011, $n^{\circ}$ 38.Disponível em: www.npd.no/en/Regulations/Acts/Petroleum-activities-act/\#Section\% 209-4. Acesso em: 25 de agosto de 2016 
ONU - Agreement relating to the implementation of Part XI of the United Nations Convention on the Law of the Sea of 10 December 1982 Overview. Disponível em: http:// www.un.org/depts/los/convention_agreements/convention_overview_part_xi.htm. Acesso em: 25 de agosto de 2016.

ORGANIZAÇÃO DAS NAÇÕES UNIDAS. Convenção das Nações Unidas sobre a Plataforma Continental, $\mathbf{N}^{\circ}$ 7302. Treaty Series: Treaties and international agreements registered or filed and recorded with the Secretariat of the United Nations, New York, vol. 499, p. 311, 1965. Firmada em 29 de abril de 1958 em Geneva - vigente em 10 de junho de 1964. Disponível em: <https://treaties.un.org/doc/Publication/UNTS/Volume\%20499/v499.pdf>. Acesso em 25 de agosto de 2016.

ORGANIZAÇÃO DAS NAÇÕES UNIDAS. Convenção das Nações Unidas sobre o Direito do Mar (com anexos, ato final e processo verbal de retificação do ato final em 3 de março de 1986 e 26 de julho de 1993), N 31363. Treaty Series, vol. 1834, I-31363, 1994. Firmada à Montego Bay em 10 de dezembro de 1982 - vigente em 16 de novembro de 1994. Disponível em: <www.un.org/depts/los/convention_agreements/texts/unclos/ unclos_f.pdf>. Acesso em 25 de agosto de 2016.

Petroleum Act 1998. United Kingdom. Disponível em: <http://www.legislation.gov.uk/ ukpga/1998/17/contents>. Acesso em: 25 de agosto de 2016.

REMOND-GOUILLOU Martine. L'exploitation petrolière en mer et le droit. Paris: Éditions Technip, 1970, p. 13 e p. 17.

Regulations to Act relating to petroleum activities (Regulamento relativo às atividades petrolíferas), n 1997-06-27-653, 27 de junho de 1997. Disponível em: <http://www.npd.no/ en/regulations/regulations/petroleum-activities/>. Acesso em: 25 de agosto de 2016.

TIMOR SEA TREATY. Disponível em: <http://timor-leste.gov.tl/wp-content/uploads/2010/03/ R_2003_2-Timor-Treaty.pdf >. Acesso em: 01 de junho 2016.

Recebido em: jun/2016 Aprovado em: ago/2016 